\title{
IMMUNOLOGICAL CHARACTERIZATION OF SOME BASEMENT MEMBRANE ANTIGENS
}

\author{
BY \\ G. LOEWI \\ Medical Research Council Rheumatism Research Unit, Canadian Red Cross Memorial Hospital, Taplow, \\ Maidenhead, Berkshire
}

In earlier publications concerned with cartilage chondromucoprotein (Loewi and Muir, 1965; Loewi, 1965), it was noted that antiserum produced against that material showed a reaction with basement membranes of various mammalian organs. The present work is concerned with an elaboration of this finding.

Basement membrane antigenic constituents have been extensively studied by many workers, e.g. Markowitz and Lange (1964); Steblay and Lepper (1961); Scott (1959); Pierce, Beals, Sri Ram, and Midgley (1964). While most workers have associated antigenic activity with reticulin or related mesothelial constituents, Pierce and his associates found an antigen of epithelial origin associated with mouse parietal yolk sac basement membrane.

Immunological reactions of basement membranes have evoked interest particularly on account of experimental nephrotoxic nephritis, where a responsible antigen was found to be in the glomerular basement membrane; here, in turn, it was localized to reticulin by Cruickshank and Hill (1953).

The work reported here was undertaken to determine the antigenic relationship between chondromucoprotein and reticulin preparations, and to compare the localization of fluorescent staining given by antisera to these antigens.

\section{Materials and Methods}

Chondromucoprotein.-This was prepared from pig laryngeal cartilage by Dr. Helen Muir. The analysis of this material and the characteristics of rabbit antibody obtained against it have been fully described elsewhere (Muir, 1958; Loewi and Muir, 1965).

Reticulin.-A preparation (the term reticulin is used throughout without implying either histological or chemical purity) was obtained from pig spleen following the method of Snellman (1963). Pieces of spleen were rubbed under water with occasional centrifugation and washing until a yellowish material was left from which no further cells or haemoglobin were released on further washing. This was dehydrated in acetone, followed by drying at $37^{\circ} \mathrm{C}$. The dry material was ground as finely as possible and then fat-extracted with equal volumes of acetone and benzene in a Soxhlet apparatus. The resulting material had nitrogen content of 11.4 per cent., hydroxyproline $3 \cdot 1$ per cent. (method of Stegemann, 1958), and anthrone 8.6 per cent. No hexosamine was found. Galactose was shown by chromatography. A two-dimensional chromatogram showed an amino-acid distribution qualitatively resembling that of collagen.

Enzyme Treatment.-Collagenase ABC form II was dissolved at $1 \mathrm{mg} . / \mathrm{ml}$. in $0.1 \mathrm{M} \mathrm{NaCl}, 0.1 \mathrm{M} \mathrm{CaCl}_{2}$, and $0.05 \mathrm{M}$ borate at pH 7.0. Crystalline trypsin was used at $1 \mathrm{mg} . / \mathrm{ml}$. in $\mathrm{M} / 15$ phosphate buffer $\mathrm{pH} \mathrm{8.0.} \mathrm{Papain}$ was used in accordance with the method of Scott (1960). Reticulin was usually sonicated in order to get a solution or fine suspension before enzymes were added. Enzyme treatment was followed by dialysis and freeze-drying.

Antisera.-These were produced in rabbits and guineapigs by foot-pad immunization with a solution or suspension of antigen emulsified with an equal volume of Freund's complete adjuvant. The activity of sera was assessed by diffusion in agar, by tanned-cell haemagglutination, and haemagglutination-inhibition (for methods, see Loewi and Muir, 1965). The fluorescent staining technique was carried out by the indirect method, using either fresh-frozen or cold-ethanol fixed tissue; for technical details, see Loewi (1965).

\section{Results}

Sera from both guinea-pigs and rabbits immunized with pig spleen reticulin showed only a weak precipitation line with sonicated reticulin, and such lines were in part due to antibody to pig serum. When, however, reticulin was first treated with collagenase (Fig. 1, opposite) and the collagenase-treated material was then allowed to diffuse against antiserum, prominent precipitation bands appeared. These bands were not due to serum contamination, a 


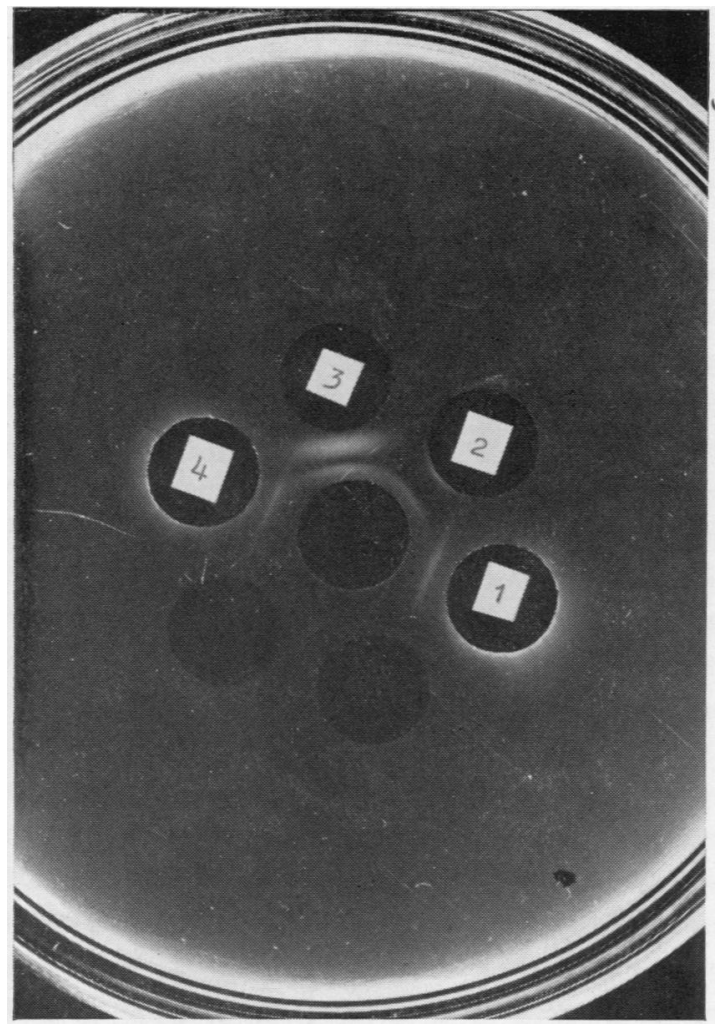

Fig. 1.-Reactions of pig spleen reticulin antiserum (centre well), with 1 and $4=$ pig serum, $2=$ sonicated reticulin, $3=$ collagenasetreated reticulin.

point further documented when antiserum absorbed with pig serum was used. Collagenase treatment caused a reduction of hydroxyproline content from $3 \cdot 1$ to 0.5 per cent. Treatment with trypsin produced only one precipitation line, which showed a reaction of identity with one of the collagenase-recticulin lines. Pepsin- or papain-treated reticulin showed no precipitation reactions with antiserum. There was no reaction between any of the anti-reticulin sera and chondromucoprotein, with or without prior hyaluronidase treatment. Controls showed no reaction between collagenase or trypsin and anti-reticulin sera. Reactions with sonicated pig kidney glomerulus preparations (method of Steblay and Lepper, 1961) were found to be largely due to contaminating pig serum.

Haemagglutination carried out with erythrocytes coated with sonicated spleen reticulin and anti-pig spleen reticulin serum absorbed with pig serum gave a titre of 1:800; when cells coated with collagenase-treated reticulin were used, the titre was $1: 1600$. Porcine chondromucoprotein was used as a potential inhibitor of this haemagglutination at concentrations of from 10 to $100 \mu \mathrm{g}$. per well; no inhibition was found. Similarly, there was no inhibition when a system of cells coated with chondromucoprotein and antibody to chondromucoprotein was exposed to reticulin as the inhibitor of agglutination. A crude preparation of pig collagen (12 per cent hydroxyproline) similarly failed to inhibit agglutination of reticulin-coated cells by anti-reticulin serum.

The staining of various basement membranes by antisera using the fluorescent antibody technique is shown in a series of illustrations (Figs $2-11$, overleaf).

Anti-reticulin serum was used after absorption with pig serum, while anti-chondromucoprotein serum did not require such absorption; this antiserum gave no reaction with pig serum, and absorption prior to fluorescent staining did not reduce the intensity of staining. Structures of the basement membrane region were stained by both anti-reticulin and anti-chondromucoprotein sera in trachea, kidney, choroid, thyroid, skin, and muscle. Both types of antiserum gave staining of porcine tissue, which was the source of antigen, as well as of bovine tissues. A variable amount of staining was seen with human tissues, but this was always less intense than that with porcine or bovine tissues. The antisera were exhaustively absorbed with the heterologous antigens, i.e. anti-reticulin with chondromucoprotein and anti-chondromucoprotein with reticulin. This led to a small but definite decrease in staining intensity in both cases. Absorption with the homologous antigen led to abolition of staining. Collagen was not stained by these antisera in any section examined, while cartilage and interfibrillar material of connective tissue were only stained by the antiserum to chondromucoprotein. The staining of basement membrane regions with anti-chondromucoprotein was not noticeably enhanced by prior treatment of the section with hyaluronidase, as was the staining of cartilage (Loewi, 1965).

\section{Discussion}

There are several findings in pathological states, both natural and experimental, which point to the basement membrane as an important locus of disease. Thus, the renal lesion of systemic lupus erythematosus includes abnormalities of the glomerular basement membrane (Holman, 1965), and the capillary basement membrane in muscle biopsies was seen to be thickened in scleroderma (Norton, 


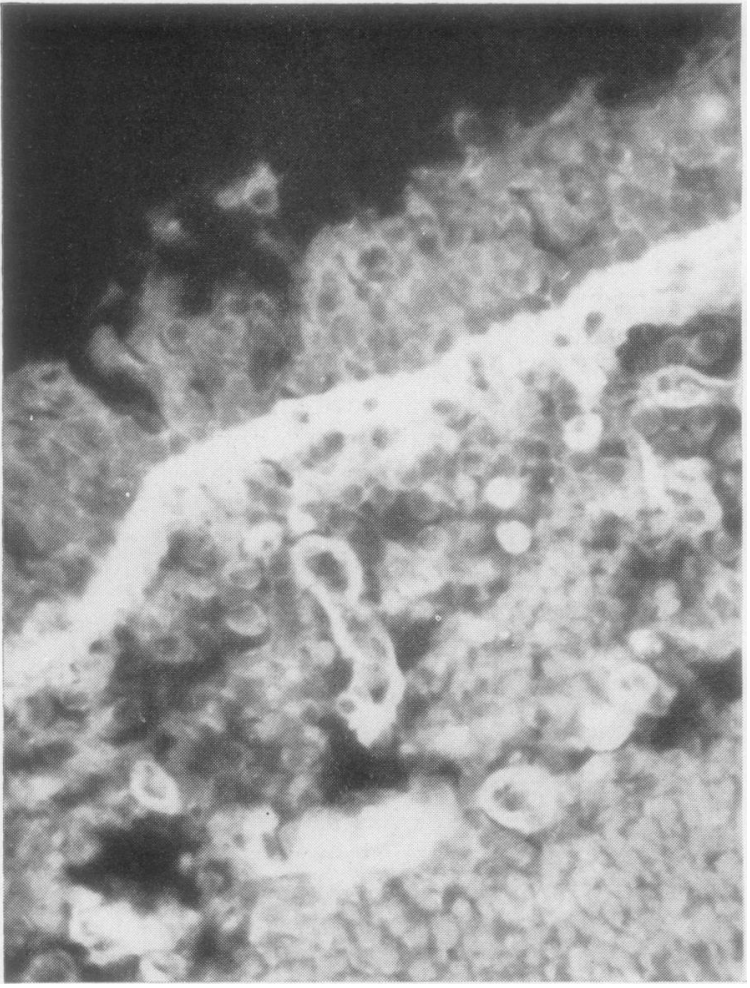

Fig. 3.-Section of tracheal mucosa treated with rabbit anti-reticulin serum, after absorption with pig serum.

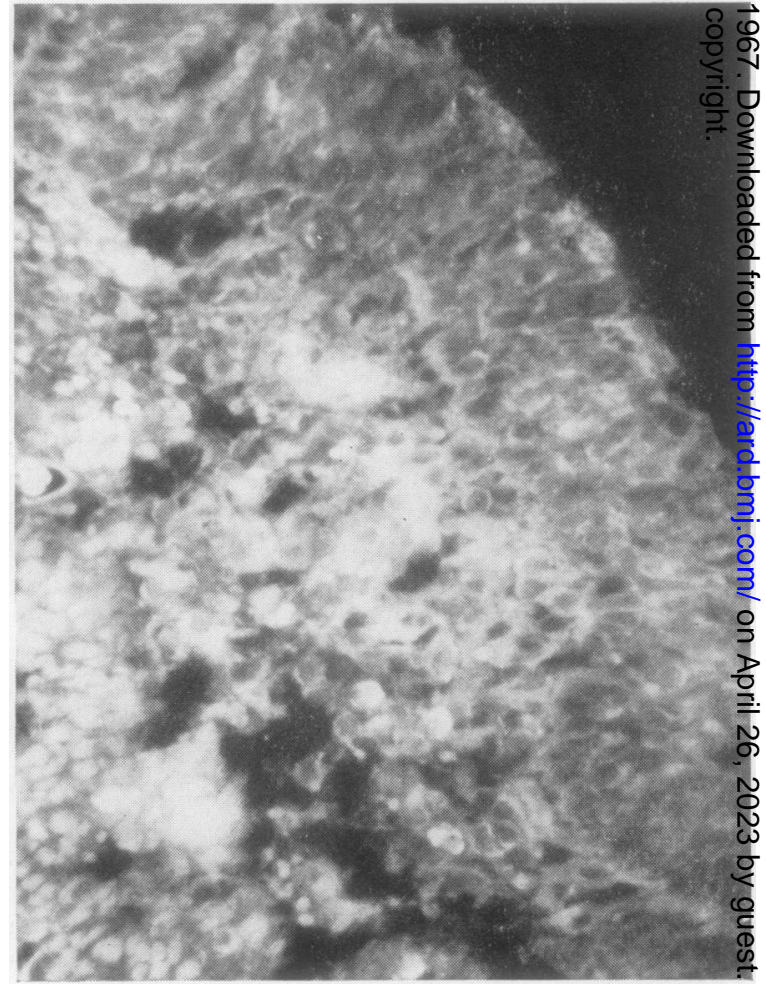

Fig. 4. - Section of tracheal mucosa treated with control rabbit serum.

Fig. 2.-Section of tracheal mucosa (cold-alcohol fixed) treated with rabbit anti-chondromucoprotein serum followed by goat-anti-rabbit serum conjugate. Basement membrane is brightly stained. Autofluorescence of elastin and collagen. $\times 240$.

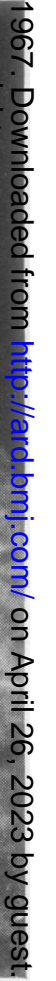




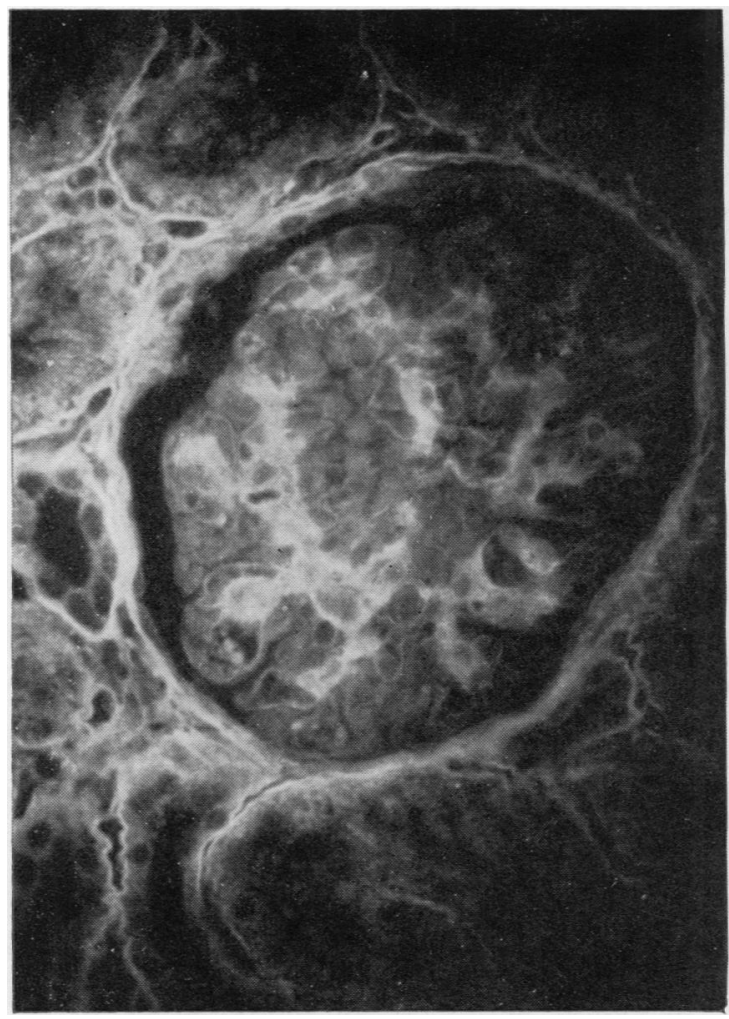

Fig. 5.-Section of pig kidney treated with rabbit anti-chondromucoprotein serum and conjugate. Glomerular and tubular basement membranes are stained. $\times 240$.

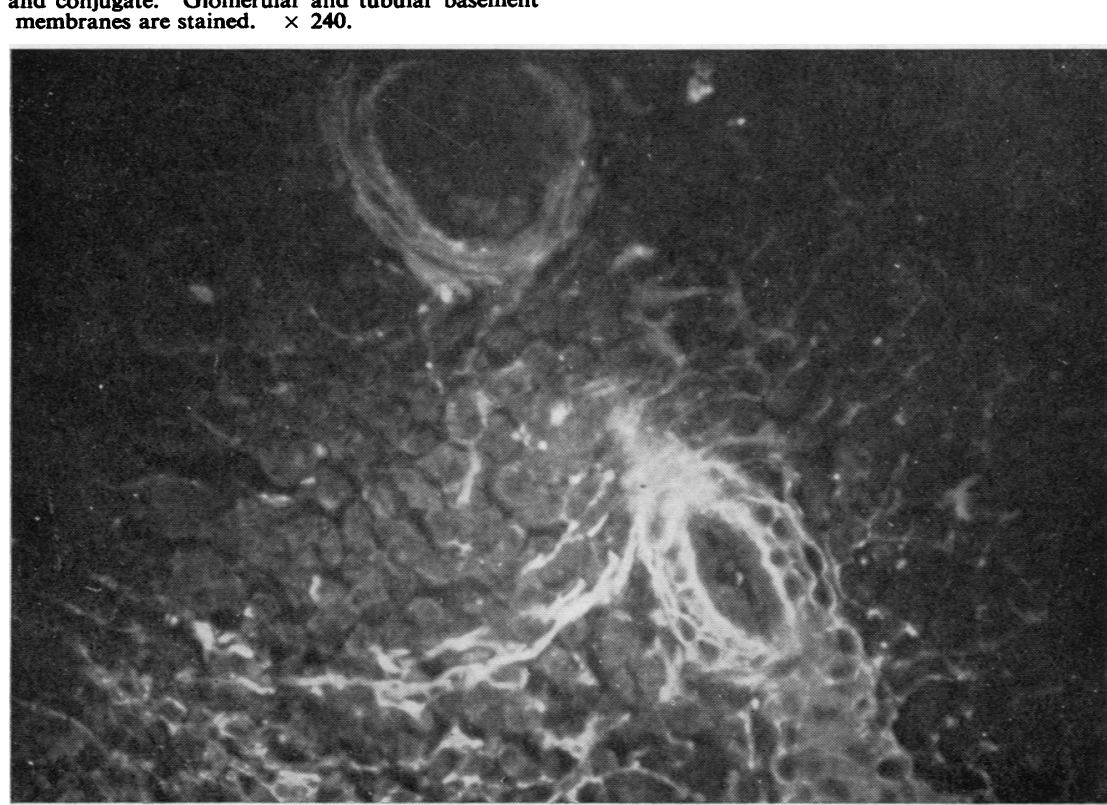

Fig. 7.-Section of pig spleen treated with anti-chondromucoprotein serum and conjugate. Recticular network in pulp and around blood vessels is stained. $\times 240$.

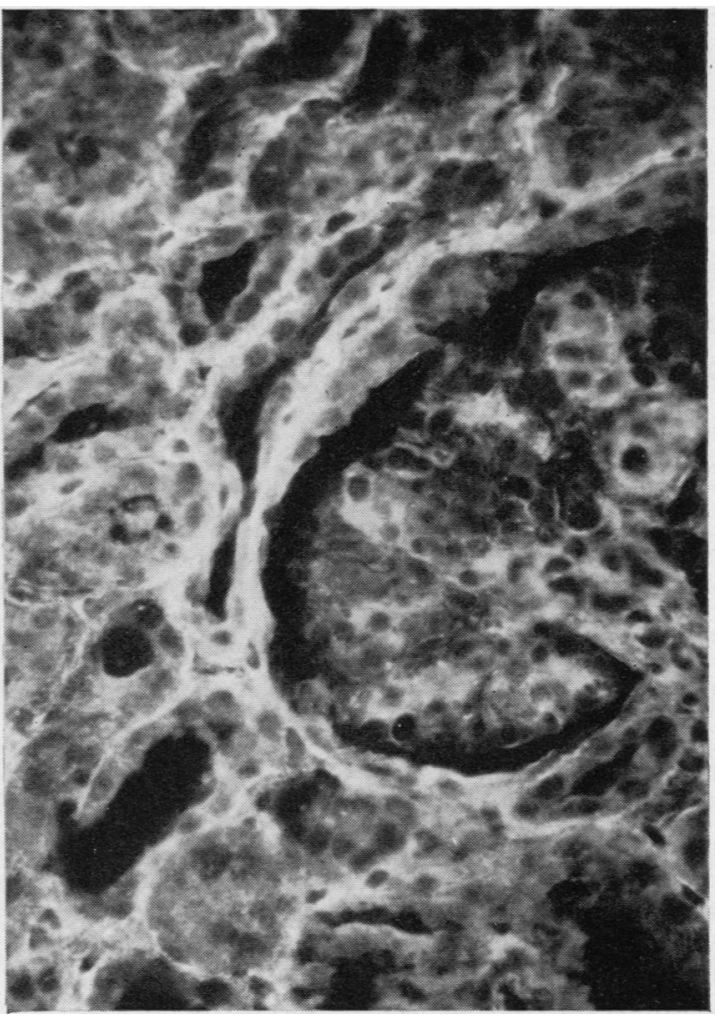

Fig. 6.-Section of pig kidney treated with anti-reticulin serum. 


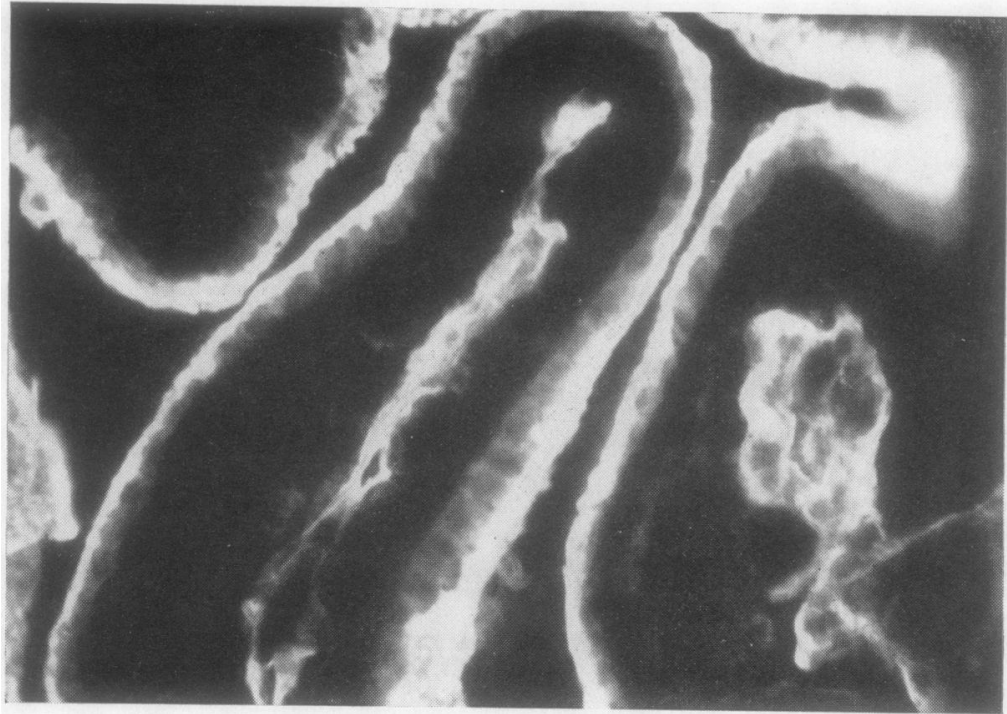

Fig. 8.- Section of pig choroid treated with anti-reticulin serum and conjugate. Basement membrane is strongly stained. $\times 240$.

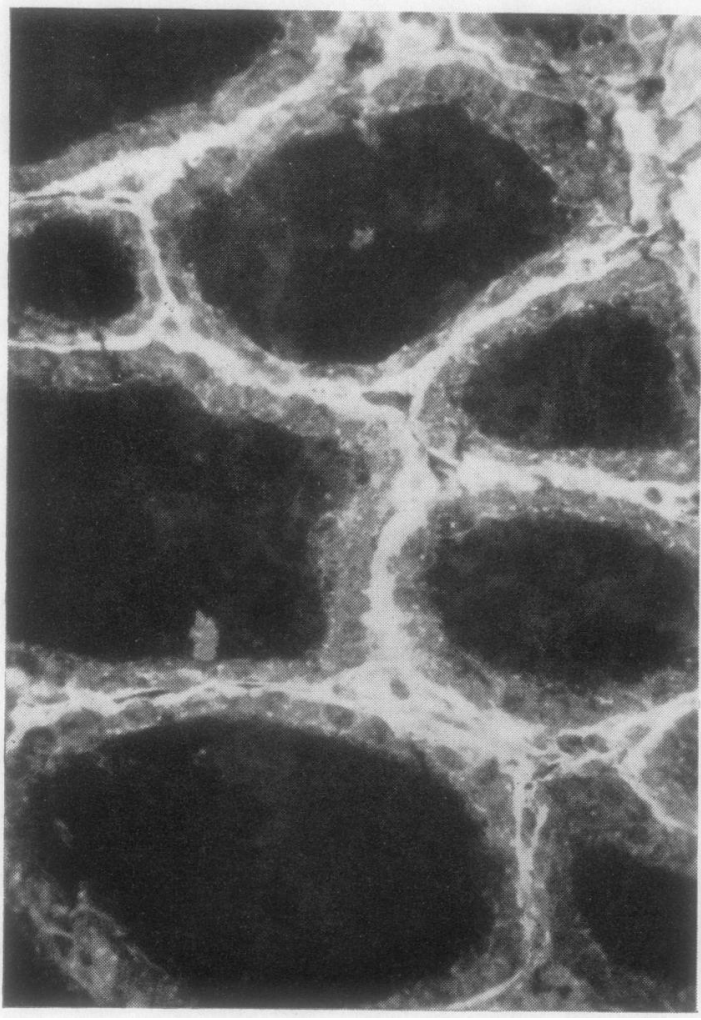

Fig. 9.- Section of calf thyroid (unfixed cryostat section) treated with anti-pig-chondromucoprotein and conjugate. Basement membrane is strongly stained. $\times 240$.

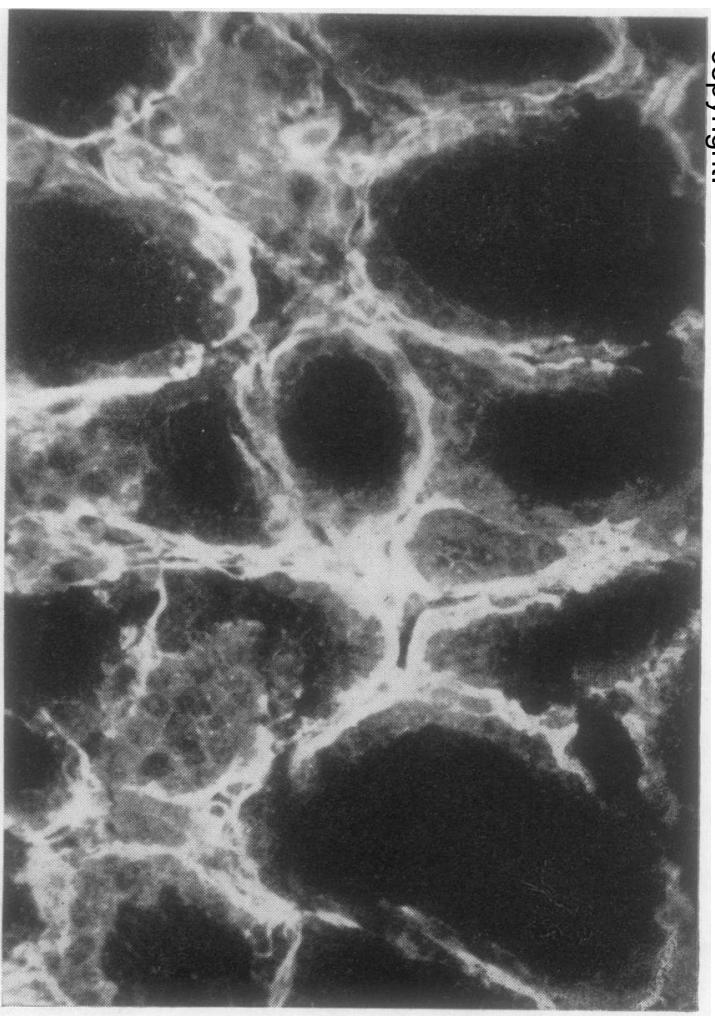

Fig. 10.-Section of calf thyroid treated with anti-pig reticulin serum.

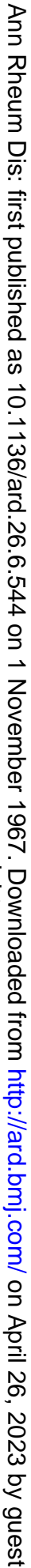

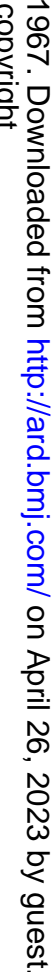

뭉
$\stackrel{0}{\mathbb{D}}$
$\stackrel{0}{\mathbb{1}}$
$\stackrel{0}{0}$ 


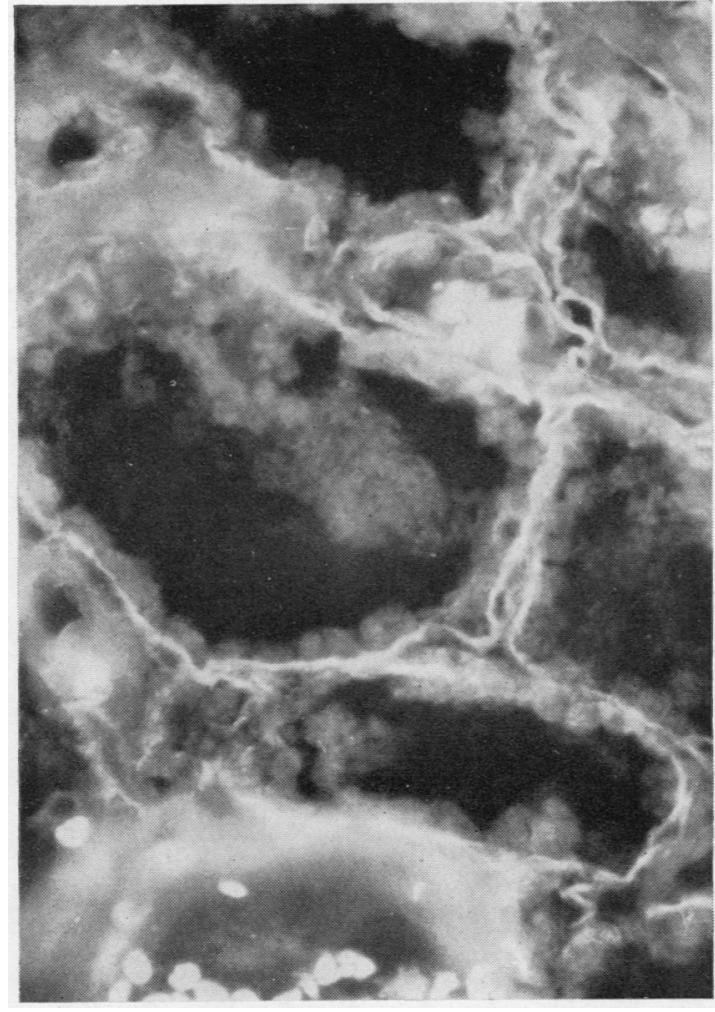

Fig. 11.-Section of human thyroid (cold-alcohol fixed) treated with anti-pig reticulin serum and conjugate. Basement membrane is stained. $\times 240$

Hurd, and Ziff, 1966). In experimental nephrotoxic nephritis, the basic lesion consists of an accumulation of electron dense material on the endothelial side of the glomerular basement membrane which coincides with the fixation of antibody and complement in this site (Feldman, 1963). Further, glomerulo-nephritis has been induced experimentally by the injection of heterologous glomerular basement membrane (Steblay, 1963). Such findings indicate the importance of elucidating the structure and composition of the basement membrane region. The present paper is concerned with an immunological analysis of two constituents associated with basement membrane. Similar approaches have been used by various other investigators. Scott (1959) used anti-human glomerulus and anti-human-synovium sera and found that basement membranes, reticulin, and a group of so-called connective tissue components reacted with the former antiserum, while only reticulin and connective tissue components reacted with the latter. Markowitz and Lange (1964) found an immunological cross-reaction between human glomeruli and cell membranes of nephritogenic strains of streptococci, and obtained low molecular weight glycoproteins from both sources. Rothbard and Watson (1967) obtained an immunofluorescent reaction in the glomerular basement membrane of human kidneys which had been perfused with antihuman-collagen serum. Collagenase pre-treatment prevented this reaction; it was concluded that collagen in human basement membrane was the relevant antigen. Another immunological approach to the problem of basement membrane constituents was made by Tan and Kaplan (1963), who found an antigen in mouse basement membranes which reacted with antiserum to a mouse serum globulin fraction. Pierce and others (1964) have extensively investigated a material in some mouse basement membranes which is antigenically identical with a mucoprotein from Reichert's membrane, synthesised by the cells of the parietal yolk sac. This constituent is antigenically distinct from connective tissue, and is particularly noteworthy for its epithelial, as opposed to a mesothelial, origin.

To these various constituents of basement membrane we may now add one which reacts with antiserum directed against chondromucoprotein. This may be one of the constituents of the chondromucoprotein complex, or an antigenically related material. That chondromucoprotein is antigenically distinct from a preparation of reticulin obtained from spleen is shown by the absence of serological cross-reactions, although absorption of antisera suggested some degree of antigenic similarity when tested by fluorescent staining. This may be due to an impurity present in both preparations, or to a component common to connective tissue materials, as described by Goldstein, Halpern, and Robert (1967), who found cross-reactions between glycoprotein preparations from human aorta, bovine cornea, and heart valves. Collagen was left unstained, and no serological reaction could be shown with a preparation of collagen from pig skin. The effect of collagenase on the serological reactivity is explicable in terms of some degradation of reticulin which is closely related to collagen (it is not claimed that the material from spleen was free from collagen). Degradation of reticulin would make it more diffusible through agar and might reveal antigenic constituents not previously available for reaction with antibody (see Fig. 1). Hyaluronidase similarly enhances the reaction of chondromucoprotein with antiserum. Immunofluorescence showed cross-reaction of the anti-reticulin and anti-chondromucoprotein antisera with basement membranes of various species. This lack of species- 
specificity is also shown by the work of Steblay (1963), who was able to produce glomerulo-nephritis in sheep by the injection of human, monkey, rabbit, rat, or dog glomerular basement membrane and adjuvant.

\section{Summary}

Antiserum to chondromucoprotein derived from porcine cartilage was found to react with basement membranes of various organs of several species by immunofluorescence. Antiserum directed against a porcine spleen reticulin preparation was prepared in rabbits and guinea-pigs. This showed immunological reactions with sonicated reticulin, which were considerably enhanced by treatment of the antigen with collagenase. Anti-reticulin serum gave fluorescent staining of basement membranes. No serological cross-reactivity between chondromucoprotein and reticulin was found. Although immunofluorescent staining of the basement membrane region by anti-reticulin was somewhat reduced by absorption of the serum by chondromucoprotein, as was the staining with anti-chondromucoprotein when absorbed with reticulin, it is concluded that these two constituents are separately represented in basement membranes.

I am grateful to Miss A. Temple for excellent assistance and to Dr. H. Muir for chondromucoprotein.

\section{REFERENCES}

Cruickshank, B., and Hill, A. G. S. (1953). J. Path. Bact., 66, 283 (The histochemical identification of a connective tissue antigen in the rat).

Feldman, J. D. (1963). In "Immunopathology, 3rd International Symposium, California, 1963," ed. P. Grabar and P. A. Miescher, p. 263. Schwabe, Basel.

Goldstein, I., Halpern, B., and Robert, L. (1967). Nature (Lond.), 213, 44 (Immunological relationship between streptococcus, a polysaccharide and the structural glycoproteins of heart valve).

Holman, H. R. (1965). In "Immunological Disease," ed. M. Samter, p. 737. Little, Brown, Boston.

Loewi, G. (1965). Ann. rheum. Dis., 24, 528 (The localization of chondromucoprotein in cartilage).

— and Muir, H. (1965). Immunology, 9, 119 (The antigenicity of chondromucoprotein).

Markowitz, A. S., and Lange, C. F. (1964). J. Immunol., 92, 565 (Streptococcal related glomerulonephritis. 1. Isolation, immunochemistry and comparative chemistry of soluble fractions from type 12 nephritogenic streptococci and human glomeruli).

Muir, H. (1958). Biochem. J., 69, 195 (The nature of the link between protein and carbohydrate of a chondroitin sulphate complex from hyaline cartilage).

Norton, W., Hurd, E., and Ziff, M. (1966). Arthr. and Rheum., 9, 870 (A capillary abnormality in scleroderma).

Pierce, G. B., Beals, T. F., Sri Ram, J., and Midgley, A. R. (1964). Amer. J. Path., 45, 929 (Basement membranes. IV. Epithelial origin and immunologic cross reactions).

Rothbard, S., and Watson, R. F. (1967). J. exp. Med., 125, 595 (Demonstration by immunofluorescence of the fixation of perfused antibody to human collagen in human kidney).

Scott, D. G. (1959). Ann. rheum. Dis., 18, 207 (An immuno-histological study of connective tissue).

Scott, J. E. (1960). In "Methods of Biochemical Analysis," ed. D. Glick, vol. 8, p. 145. Interscience, New York and London.

Snellman, O. (1963). Acta chem. scand., 17, 1049 (A glycoprotein from reticulin tissue).

Steblay, R. W. (1963). In "Immunopathology, 3rd International Symposium, California, 1963," ed. P. Grabar and P. A. Miescher, p. 252. Schwabe, Basel.

and Lepper, M. H. (1961). J. Immunol., 87, 636 (Some immunologic properties of human and dog glomerular basement membrane. II. Nephritis produced in dogs by rabbit antihuman glomerular basement membrane sera).

Stegemann, H. (1958). Hoppe-Seyler's Z. physiol. Chem., 311, 41 (Mikrobestimmung von Hydroxyprolin mit Chloramin-T und Pp-Dimethylaminobenzaldehyd).

Tan, E. M., and Kaplan, M. H. (1963). Immunology, 6, 331 (Immunological relation of basement membrane and a serum beta globulin in the mouse. Demonstration of renal basement membrane alteration in mice injected with streptolysin S). 
La caractérisation immunologique de quelques antigènes de la membrane basale

\section{RÉSUMÉ}

On a trouvé qu'un sérum anti-chondromucoprotéine préparé à partir de cartilage de porc réagissait par immunofluorescence avec les membranes basales de différents organes de différents espèces. Un antisérum réagissant contre une préparation de réticuline de rate porcine a été préparé chez des lapins et des cobayes. On a obtenu des réactions immunologiques avec cette réticuline et celles-ci étaient considérablement accentuées par un traitement préalable de l'antigène par la collagénase. Le sérum anti-réticuline a provoqué une coloration fluorescente des membranes basales. On n'a pas trouvé de réactivité sérologique croisée entre la chondromucoprotéine et la réticuline. Bien que la coloration immunofluorescente de la région de la membrane basale par l'antiréticuline soit quelque peu réduite par l'absorption du sérum par la chondromucoprotéine, comme la coloration avec l'anti-chondromucoprotéine lors de l'absorption par la réticuline, on conclut néanmoins que les deux constituants sont présents séparement dans les membranes basales.
La caracterización inmunológica de algunos antígenos de la membrana basal

SUMARIO

Se observó que un suero anti-condromucoproteina derivado del cartílago porcino reaccionaba por inmunofluorescencia con membranas basales de varios órganos de diferentes especies. Un antisuero contra una preparación de reticulina del bazo porcino fué preparado en conejos y cobayos. Se obtuvieron reacciones inmunológicas con esta reticulina que fueron más fuertes después de tratar el antígeno por la colagenasa. El suero antireticulina produjo una coloración fluorescente de las membranas basales. No se encontró reactividad serológica cruzada alguna entre ia condromucoproteina y la reticulina. Aunque la coloración inmunofluorescente de la región de la membrana basal por la anti-reticulina fuera algo reducida por la absorpción del suero por la condromucoproteina, asimismo que la coloración con la anticondromucoproteina durante la absorpción por la reticulina, se puede sin embargo concluir que ambos constituyentes se ven representados separadamente en las membranas basales. 